УДК $82.091: 477$

DOI: $10.31558 / 2308-1902.2019 .27 .6$

\author{
Валентина КРАСНІКОВА \\ кандидат філологічних наук, доцент, \\ Донецький національний університет \\ імені Василя Стуса
}

\title{
ІСТОРИЧНЕ МИНУЛЕ У ВІЗІї ВОЛОДИМИРА СОСЮРИ
}

У статті здійснено комплексний аналіз історичного епосу В. Сосюри на матеріалі поем «Махно» і «Мазепа», роману у віршах «Тарас Трясило». Відзначається, що тематиці боротьби В. Сосюра присвятив низку творів, в яких письменник-епік позитивними персонажами обирає історичну постать - Нестора Махна й Івана Мазепу. Також у статті 3'ясовано причини звернення В. Сосюри до постаті Тараса Трясила.

Ключові слова: епічні твори, історична тематика, національно-визвольна боротьба.

Постановка проблеми в загальному вигляді. В історію української літератури В. Сосюра увійшов як поет непростої долі, складного емоційнопсихологічного реагування на світ. Усе, що йому судилося пережити, - від служби в петлюрівському війську, а потім переходу до більшовиків, - автор щиро зобразив у своїх творах. Через власні переживання та оцінки В. Сосюра осмислює історію, далеку і близьку, особливо періоду 1920-х років. 3'являються його поеми «Червона зима», «1916 рік», «Навколо», «Золотий ведмедик», «Осінні зорі» та ін. Таким чином, поет мав досвід епічного осмислення минулого. Твори на історичну тематику - нове слово в художньому доробку В.Сосюри, де повною мірою виявлено життєве та естетичне кредо поета.

Формулювання цілей статті. Метою цієї статті $є$ комплексний аналіз історичного епосу Володимира Сосюри на матеріалі поем «Махно» i «Мазепа», а також роману у віршах «Тарас Трясило». Теоретикометодологічною основою для дослідження послужили праці О. Білецького, М. Зерова, С. Єфремова, Д. Чижевського. Певним теоретичним підгрунтям роботи стали сучасні дослідження Ю. Барабаша, В. Моренця, С. Гальченка, 
М. Ткачука, в яких склалася концепція поетичного доробку В. Сосюри, зокрема художньої специфіки його творів.

Виклад основного матеріалу. Сучасники В. Сосюри схильні до думки, що він був непередбачуваним. Ця непередбачуваність полягала в тому, що для поета не існувало заборонених тем чи одіозних постатей. Непередбачуваність ця йшла не від нестабільності психологічного стану чи непередбачуваності поведінки. Поет був прогнозований, і логіка його мислення йшла від творчих імпульсів, детермінованих таємницями творчої лабораторії. Піднімаючи завісу цієї лабораторії, оприлюдненої в «Третій роті», бачимо, що іiі індикатором була поетова щирість. Всупереч політичній ситуації у країні В. Сосюра звертався не до замовних тем, а до того, що йшло від серця, що він вважав вартим уваги, і не за усталеними зразками, а за покликами серця й сумління, які самі поєднували слова, фрази у поеми і романи.

До найповніших видань творів поета не були включені його поеми, де йшлося про репресованих діячів науки i культури, одіозних постатей української історії. Таким твором є поема «Махно», написана В. Сосюрою 1924 р., текст якої в архіві поета не зберігся. Певно, автор мав намір відновити 3 пам'яті втрачений твір про Махна в новій поемі «Розстріляне безсмертя», яку створив уже 1960 р. Принаймні початок поеми «Розстріляне безсмертя» дає привід думати саме так:

\section{Ти знов стоїш переді мною}

й в поему просишся, Махно! [1, с. 93].

Криваві епізоди розправи над махновцями, які згадуються у романі «Третя Рота», свідчать про небайдуже ставлення поета до махновщини. Ще однією причиною звернення В. Сосюри до складної і суперечливої постаті Махна було захоплення в юнацькі роки анархістськими ідеями. Приваблювала поета і особистість самого ватажка, який у 1918-1920 pp. боровся, по-суті, проти всіх влад, які існували на той час. Болісно звучать рядки-звернення до Махна, що підтверджують, що автор щиро співчуває своєму героєві: 
Твоєю я забризкав кров'ю

Сніги широкі та сумні

І все ж любив тебе любов'ю,

Незрозумілою мені [1, с. 94].

Можливо, це й $є$ пояснення - виправдання поета за зображення забороненої постаті. Отже, поема «Махно» В. Сосюри - безцінний документ бурхливої історії, спроба правдивого висвітлення її автором.

Традиційним для зарубіжних та українських митців $є$ образ гетьмана Мазепи, до якого звернувся і В. Сосюра у своій однойменній поемі. Уперше цей загадковий український гетьман знайшов відображення у жанрі од і панегіриків за часів свого гетьманування. Ф. Прокопович присвятив гетьманові трагікомедію «Володимир». По смерті Мазепи почалося осмислення його діяльності в історіографічних працях, серед яких найважливіші «Опис» Григорія Покаса, «Літопис» Самійла Величка, «Історія Русів», але ці джерела дійшли до широкого читача лише у другій половині XIX ст.

На початку XVIII ст. постать українського гетьмана приваблювала багатьох зарубіжних письменників. Серед них слід відзначити «Історію Карла XII» - перший історичний твір відомого французького просвітителя Вольтера. У романтичному дусі образ гетьмана осмислений Дж. Байроном, який пише 1818 р. поему «Мазепа». Цю традицію продовжує В. Гюго поемою «Мазепа». Були написані і драматичні твори, присвячені українському гетьманові: німецький письменник Р. Готшаль пише трагедію «Мазепа», свій варіант трагедії про Мазепу створив польський письменник Ю. Словацький.

В українській літературі до образу Мазепи та його доби звертався T. Шевченко у містерії «Великий льох», у поезіях «Чернець», «Іржавець» та повісті «Музикант». Продовжив традиції Т. Шевченка С. Руданський твором «Мазепа, гетьман український. Поема історична». Пізніше про гетьмана писали П. Куліш, Б. Лепкий, Ю. Мушкетик, Р. Іваничук.

Зображуючи постать Івана Мазепи, В.Сосюра намагається осмислити сьогочасні проблеми - особисті та суспільні. «В. Сосюра намагається до кіния 
збагнути не так, може, Мазепу, як самого себе, розв'язати у свой свідомості й у сериі не лише застарілі історичні, а й не менш болючі сьогоденні вузли» [2, с. 143].

На відміну від попередників (Дж. Байрона, В. Гюго, Ю. Словацького), В. Сосюра створює свій образ гетьмана. С. Гальченко зазначає: "Не ідеалізуючи його як неординарну особистість, поет творить насамперед художній образ, а не політичний портрет гетьмана" [3, с. 15].

Поема В. Сосюри - це епічний твір з яскраво вираженою ліричною тональністю, де розповідь про життя гетьмана переплітається 3 ліричними відступами, які розкривають тривогу душі самого автора, його нелегкі життєві і творчі пошуки. В. Моренець підкреслює: «Це велике, замислене в епічних вимірах полотно, ще раз увиразнює власне ліричний талант Сосюри, для якого переживання подій було завжди ближчим за їх осмислення» [4, с. 15]. Не можна не згадати і статті М. Ткачука, в якій зазначено, що поет «сміливо пішов далі за своїх сучасників у трактуванні болючих сторінок історії Украӥни й Росії. Досліджуючи невигоєні рани украӥнського народу і його історії, він піднявся вище за своӥх російських побратимів по перу, як $i$ багатьох українських істориків, митців у трактуванні "заборонених тем", в оцінці nостаті Мазепи» [5].

Поема «Мазепа» написана у сосюринській манері, що становить своєрідне поєднання реальних історичних подій з романтичними сторінками любовних пригод Мазепи, епіко-філософських узагальнень, насичених експресивними авторськими оцінками, почуттями, враженнями.

Слова ніжності та любові до України, висловлені у пролозі до поеми «Мазепа», лунають своєрідним заспівом до всього твору:

$O$, як люблю я рідний край

І в щуастя мить, і у негоду [6, с. 77].

Для глибшого розкриття образу гетьмана В. Сосюра використовує прийом зіставлення з постаттю донощика Кочубея. Поштовхом до написання доносу, за В. Сосюрою, були скривджені почуття старої Кочубеїхи. Неабияке 
місце відводиться і роману Мазепи з донькою Кочубея - Мотрею. Справді, в цих епізодах поеми автор зазнає творчої невдачі. Якщо вірити В. Сосюрі, то гетьман кохається не тільки з хрещеницею, а з рідною дочкою, знаючи про це. Натомість, уся ця історія з вигаданим коханням увиразнює ліричну душу автора, який нагромаджує авантюрні колізії, зображуючи зазначені події.

Суттєвий ідейний зміст вкладено у сни-марення Мазепи. Через сновидіння зображені дитинство і юність героя, подано благословіння матерічерниці «бути оборонщем Украӥни» [6, с. 86]. Старенька мати (вона подана у творі як втілення українського сумління Мазепи і носій авторської позиції) говорить:

Стань на чолі, здійми повстання,

Нехай чека тебе за теє

Страшна дорога Моїсея [6, с. 86].

Цитовані рядки окреслюють певну типологічну подібність у розв'язанні проблеми вождя i народу у В.Сосюри та I. Франка. Але якщо Великий Каменяр цю проблему розв'язує на біблійному матеріалі, то В. Сосюра звертається до однієї з найтрагічніших сторінок життя українського народу. Уві сні герой переноситься у майбутнє, бачить себе гетьманом. Та не тільки у снах автор подає перебіг усієї долі Мазепи, призначеного самим Богом бути захисником рідної землі. В. Сосюра творить насамперед художній образ свого героя, намагається розкрити психологію справжнього борця за Україну. Цим і близький гетьман авторові, який намагаючись зрозуміти свого героя, хоче розібратися і в собі. Основні фабульні лінії поеми - трагедія головного героя і трагедія поневоленої України - переплітаються між собою. Проблему трагедії автор намагається тримати в полі зору і прочитує їі серцем:

Я серием хочу показать

Страшну трагедію Мазепи,

I в ній в той час страшний незгоди

Трагедію мого народу [6, с. 91]. 
Автор зі співчуттям зображує трагедію видатного політичного діяча України, пов'язану не тільки з розривом із російським царем, а й союзом зі шведами. Зрозуміло, не всі авторські оцінки тих подій вдалі й безапеляційні, та ми не беремося ні засуджувати, ні виправдовувати В. Сосюру. Засуджувати когось 3 позицій нашого часу дуже легко, але важко засуджувати справедливо, тому що не кожен може поставити себе на місце поета в ту неспокійну добу. Головне, що В. Сосюра пішов далі за своїх побратимів по перу у зображенні болючих тем історії, показі ролі Мазепи в національному історичному процесі.

Серед епічних творів В. Сосюри на історичну тематику особливе місце посідає роман у віршах «Тарас Трясило». В основу твору покладено події 1630 p., коли група запорізьких козаків на чолі з Тарасом Трясилом виступила проти військ польського гетьмана С. Конецпольського. Постать народного ватажка Тараса Трясила приваблювала і Т. Шевченка, який присвятив йому поему «Тарасова ніч». Про Тараса Трясила згадує Т. Шевченко у поемі «Гайдамаки» та повісті «Близнята»; події «Тарасової ночі» описує П. Куліш у поемі-хроніці «Україна».

Можемо тільки здогадуватися, що змусило В. Сосюру звернутися до цієї сторінки з історії України. Таким поштовхом, можливо, було українське відродження 20-х років, яке стало пошуком відповіді на сьогочасні проблеми в минулому. Головне, що твір мав надихнути читачів гідним прикладом 3 власної історії. Незважаючи на це, досить критичну оцінку романові дав М. Зеров. Відомий поет i літературний критик виходив насамперед iз естетичних критеріїв неокласичної школи, яка вимагала досконалого знання вітчизняної та зарубіжної історії, високого естетизму тощо.

М. Зеров звертає особливу увагу на невідповідність художнього осмислення однієї з найяскравіших сторінок минулого України. Він вказує на «безпорадність» перед історичним сюжетом, зазначає, що уявлення про козацьких отаманів та гетьманів взяті із Тараса Бульби та своїх спогадів про козаків та гайдамак 1918 р. [8]. Ми не заперечуємо впливу твору М. Гоголя і наслідування певних літературних традицій, все ж відзначаємо, що В. Сосюра правдиво відтворив події «Тарасової ночі». Ці події автор зобразив з позицій 
неоромантичного світосприйняття. Епічний час, відображений у творі, спроектовано у сучасність.

Не можна не згадати й оцінку роману О. Білецьким. Відзначаючи превалювання у В.Сосюри почуття над думкою, ліризму над епічним зображенням історичних подій, літературознавець констатує, що «Тарас Трясило» залишається досі чи не єдиним надрукованим твором поета, де сюжет не потонув у ліриці, де епічні контури можна більш-менш вирізнити [9, с. 117].

У творі В.Сосюри романтичний образ козацького ватажка Тараса Трясила поданий у його становленні, формуванні і розвитку. На початку твору автор показує соціальне становище свого героя. Він наймит, який працює на пана, а потім тікає від нього. Художньо-стильова своєрідність твору в симбіозі двох сюжетних ліній - показу визвольної боротьби в Україні та трагедії жінкивідступниці, яка, потрапивши в полон, перейшла в татарську віру.

Тараса не покидає мрія про вільне козацьке життя. Саме з Хортицею пов'язувалися романтичні уявлення про волю. Обставини складаються так, що Тарас змушений тікати на Січ. I ось, через два роки, він - козацький ватажок. В. Сосюра занадто соціологізує та інтернаціоналізує свої уявлення про Січ. Автор показує національну та вікову неоднорідність козаків, відтворює суперечності між отаманом та рядовим козацтвом:

А кошовий- поглянь, цุе ж кат.

Хіба изе воля в власній хаті,

Коли всім править гетьманат [10, с. 359].

Подібні конфлікти між козаками і старшиною яскраво зображені в народній думі «Ганжа Андибер» Картини визвольної боротьби також грунтуються на фольклорній традиції:

Гей, козаки, козаки, прокидайтеся

Швидие уставайте,

В'яжіть стариину, зброю одягайте,

Ворота одчиняйте, рідних братів зустрічайте,

Руки вгору іздіймайте [10, с. 43]. 
Важливу роль у сюжетній структурі твору відіграє мотив крові, який «структурує мотиви антирелігійного та класового протистояння» [11, c. 109].

Зокрема, промова Тараса Трясила:

Ми всі підем на панські мури

Топить в крові народний гнів [10, с. 54].

Відповідь козаків:

- «Веди нас, батьку» - «Хлопиі в путь!»

«Покажем ми старшині й пану

Веселу і криваву путь» [10, с. 54].

Сцена битви розлючених повстанців:

Мовчки різали селяне,

I з піснями - козаки [10, с. 70].

Мотив крові стає виправданням зрадливого вчинку сестри Тараса Марини:

Кров у степу біжить так швидко,

Любов в степу така швидка [10, с. 22].

Таким чином, створений з використанням історичних, літературних $\mathrm{i}$ фольклорних джерел, наповнений романтикою подій, роман “Тарас Трясило” відтворив найголовніше - дух буремних років юності поета.

Висновки. Отже, звернення до історичного минулого дало можливість Володимиру Сосюрі висловити роздуми про долю рідного краю. Зображуючи національні за своїм змістом події, автор дозволяє собі відхід від історичної дійсності, минуле цікавить автора у зв'язку з сучасністю.

\section{ЛIТЕРАТУРА}

1. Сосюра В. Розстріляне безсмертя. Поема. Вітчизна. 1988. №1. С. 93-107.

2. Барабаш Ю. Іван Мазепа - ще одна літературна версія. Київ. 1988. № 12. С. 140150.

3. Гальченко C. Проблеми видання спадщини В. Сосюри. Актуальні проблеми української літератури і фольклору. Випуск 1. Донецьк: Кассіопея, 1998. С. 10-19. 
4. Моренець B. Володимир Сосюра. Нарис життя і творчості. Київ: Дніпро, 1990. $261 \mathrm{c}$

5. Ткачук М. Іван Мазепа. «З думою про Україну» Відродження. 1991, 5 лютого.

6. Сосюра В. Мазепа: Поема. Вибрані твори: у 2 т. Т. 2: Поеми. Роман. Київ: Наукова думка, 2000. С. 86-179.

7. Гришко В. Серце «другого Володьки» і заборонена любов. Карби часу. Iсторія, література, політика, публічистика: у 2-х т. Київ: Смолоскип, 1999. Т. 1.868 с.

8. Зеров М. Володимир Сосюра - лірик і епік. (3 приводу роману «Тарас Трясило»). Твори. Київ: Дніпро, 1990. Т. 2 С. 505-516.

9. Белеикий А. Владимир Сосюра. Красное слово. 1928. №5. С. 148-150.

10. Сосюра В. Тарас Трясило. Роман. Харків, 1925. 80 с.

11. Багрій M. Роман у віршах Володимира Сосюри «Тарас Трясило» як зразок становлення канонів соціалістичного реалізму в українській літературі. Вісник ЛНУ імені Tapaca Шевченка. №4 (263), Ч. II. Луганськ: Видавництво Державного закладу «ЛНУ імені Тараса Шевченка», 2013. С. 106-113.

\section{REFERENCES}

1. Sosyura, V. (1988). Rozstriliane bezsmertia. Poema [The executed immortality. Poem]. Vitchyzna, (1), 93-107. [in Ukrainian].

2. Barabash, Yu. (1988). Ivan Mazepa - shche odna literaturna versiya [Ivan Mazepa another literary version]. Kyiv, (12), 140-150. [in Ukrainian].

3. Halchenko, S. (1998). Problemy vydannya spadshchyny V. Sosyury [Problems of the publication of the heritage of V. Sosyury]. Aktualni problemy ukrayinskoyi literatury $i$ folkloru, (1), 10-19. [in Ukrainian].

4. Morenets, V. (1990). Volodymyr Sosyura. Narys zhyttya i tvorchosti [Essay on life and creativity]. Kyiv: Dnipro. [in Ukrainian].

5. Tkachuk, M. (1991). Ivan Mazepa. "Z dumoyu pro Ukrayinu” [Ivan Mazepa. "With the Thought of Ukraine"]. Vidrodzhennya. (February 5). [in Ukrainian].

6. Sosyura, V. (2000). Mazepa: Poema [Mazepa: Poem]. Selected works: in 2 volumes. Vol. 2. Kyiv: Naukova dumka, 86-179. [in Ukrainian].

7. Hryshko, V. (1999). Karby chasu. Istoriya, literatura, polityka, publitsystyka [Carby of Time. History, literature, politics, journalism]. Vol. 1. Kyiv: Smoloskyp. [in Ukrainian].

8. Zerov, M. (1990). Volodymyr Sosyura - liryk i epik. (Z pryvodu romanu "Taras Tryasylo"). Tvory (Vol. 2) [Volodymyr Sosyura lyricist and epic. (About the novel "Taras Tryasylo"). Works]. Kyiv: Dnipro, 505-516. [in Ukrainian].

9. Beletskyy, A. (1928). Vladymyr Sosyura [Vladimir Sosyura]. Krasnoe slovo, (5), 148150. [in Russian].

10. Sosyura, V. (1925). Taras Tryasylo. Roman [Taras Tryasylo. Novel]. Kharkiv. [in Ukrainian].

11. Bahriy, M. (2013). Roman u virshakh Volodymyra Sosyury "Taras Tryasylo" yak zrazok stanovlennya kanoniv sotsialistychnoho realizmu $v$ ukrayinskiy literaturi [Volodymyr Sosyura's poems Taras Tryasylo as a Model of Formation of the Canons of Socialist Realism in Ukrainian Literature]. Visnyk LNU imeni Tarasa Shevchenka, (4 (263), part 2), 106-113. [in Ukrainian].

\section{АННОТАЦИЯ}

Валентина Красникова. Историческое прошлое в видении Владимира Сосюры

В статье осуществлён комплексный анализ исторического эпоса В. Сосюры на материале поэм «Махно» и «Мазепа» а также романа в стихах «Тарас Трясыло». Отмечается, что тематике борьбы В. Сосюра посвятил много произведений, где выбирает 
положительными персонажами Махно и Мазепу. Выяснены причины обращения В. Сосюры к личности Тараса Трясыло.

Ключевые слова: эпические произведения, историческая тематика, национальноосвободительная борьба.

\section{ABSTRACT \\ Valentyna Krasnikova. The historical past in Volodymyr Sosyura's vision}

The complex analysis of V. Sosyura's historical epic is given, based on the material of poems «Makhno» and «Mazepa» poems and the novel in the poems «Taras Tryasylo» as well. The reasons for V. Sosyura's interest in the epic subject are clarified. There is evidence that the historical epic was a new concept in the V. Sosyura poetry. Attention is focused on the fact that in his youth, V. Sosyura was attracted to anarchist ideas, he was interested in the figure of Makhno as the leader of the peasant masses. In his lines directed to Makhno the author expresses condolences to his hero.

V. Sosyura was interested in the traditional for foreign and Ukrainian writers is the image of Hetman Mazepa. Poem «Mazepa» is an epic work with a pronounced lyrical tone, which is a unique combination of historical events with romance of Mazepa's love story. It is emphasized that first of all the author creates an artistic image of his hero and tries to reveal the psychology of a fighter for Ukraine. The tragedy of the poem hero and the tragedy of Ukraine are bound together. It is noted that V. Sosyura goes further than other authors in depicting forbidden topics, showing the role of Mazepa in the national historical process.

A prominent place is given to the historical novel Taras Tryasylo among the other epic works. The reasons for V. Sosyura's appeal to the Cossack leader's figure are considered. The character's formation and development are exposed. In the beginning of the work the author shows the social position of his hero and sympathizes him. Together with sympathy, V. Sosyura fills his life with charismatic and even fantastic features taken from folklore. The combination of two story lines is traced: the depiction of the liberation struggle in Ukraine and the tragedy of a woman who converted into the Tatar faith after being captured.

It is concluded that the historical epic of V. Sosyura is an invaluable document from the witness of rough events.

Key words: epic works, historical subjects, national liberation struggle.

Стаття надійшла до редакиійної колегії 08.09.2019 р. Рекомендовано до друку 17.10. 2019 р. 